\title{
Üniversite Öğrencilerinin İnternet İçin Eleştirel Okuryazarlık Düzeylerinin Karşılaştırılması
}

\author{
Hasan Çiftçi (Dr. Öğr. Üyesi) \\ Harran Üniversitesi Birecik Meslek Yüksekokulu \\ hasanciftci@harran.edu.tr \\ Orcid: 0000-0001-5595-5726
}

Başvuru Tarihi: 23.12.2018

Yayına Kabul Tarihi: 08.03.2019

Yayınlanma Tarihi: 22.07.2019

DOI: 10.17680/erciyesiletisim.501027

Çiftçi, H. (2019). Üniversite Öğrencilerinin İnternet İçin Eleştirel Okuryazarlık Düzeylerinin

Karşılaştırılması. Erciyes İletişim Dergisi, 6 (2), 1341-1358. DOI: 10.17680/erciyesiletisim.501027

\section{Öz}

İnternet için eleştirel okuryazarlık; yeni medyayı aktif kullanan bireylerin kendilerine iletilen mesajlardaki içerikleri iyi değerlendirebilme, analiz edebilme ve tekrarda içerik oluşturup iletebilme becerilerini kapsamaktadır. Günümüzde bireyler internet aracılığı ile yoğun bir bilgi karmaşasına isteyerek ya da istemeyerek maruz kalmaktadır. Bireylerin sahip olacakları internet eleștirel okuryazarlık becerileri onları maruz kalacakları olumsuz içeriklerden koruyacaktır. Bu araștırmanın temel amacı, Meslek Yüksekokulu öğrencilerinde internet için eleştirel okuryazarlık düzeylerinin karşılaştırmalı olarak incelemektir. Araştırmanın çalışma grubunu 2018-2019 eğitim- öğretim yılında Gaziantep Üniversitesi Teknik Bilimler Meslek Yüksekokulu Bilgisayar Programcılığında eğitim gören 37 erkek, 77 kız toplam 114 öğrenci oluşturmaktadır. Araştırmanın verileri Dal ve Aktay (2015) tarafından geliştirilen "İnternet İçin Eleştirel Okuryazarlık Ölçeği" kullanılarak yüz yüze anket yöntemiyle yapılmıștır. Verilerin istatistiksel analizleri SPSS 22.0 programı kullanılarak yapılmıștır. Sayısal değișkenlerin normallik dağılımlarına bakmak için Shapirowilk testi uygulanmış ve normal dağılım elde edilmiștir. Veri setinde parametrik testler kullanılmıştır. Tanımlayıcı istatistiklerin çözümlenmesinde de frekans, yüzde, aritmetik ortalama, standart sapma, minimum ve maksimum değerler ayrıca grup ortalamalarının farklılıkları için bağımsız örneklem t testi ve One-way ANOVA testinden ve anlamlı sonuçlarda gruplar arası farklılıklara Tukey HSD çoklu karşılaştırma testi kullanılmıştır. Araştırmaya katılan öğrencilerinin cinsiyet, yaș, interneti kullanma sürelerine göre internet için eleştirel okuryazarlık alt boyutları puanları arasında anlamlı bir fark bulunmamıştır.

Anahtar Kelimeler: İnternet, Sosyal Medya, Eleştirel Okuryazarlık, Medya Okuryazarlığl. 


\title{
The Comparison of the University Students' Critical Literacy Level for Internet
}

\author{
Hasan Çiftçi (Asst. Prof. Dr.) \\ Harran University Birecik Vocational School \\ hasanciftci@harran.edu.tr \\ Orcid: 0000-0001-5595-5726
}

Date Received: 23.12.2018

Date Accepted: 08.03.2019

Date Published: 22.07.2019

DOI: 10.17680/erciyesiletisim.501027

\begin{abstract}
Critical literacy for the Internet includes the ability to evaluate, analyze and recreate and transmit content of messages to people who actively use the new media. Today, individuals are exposed by the intense complexity of information through the internet. Individuals' internet critical literacy skills will not only possess but also protect them from the negative content they would be exposed. The main purpose of this study is to examine the critical literacy levels of the students in the vocational high schools comparatively. Group of research have been conducted between 2018 and 2019 academic year of Gaziantep University Technic Sciences Vocational programming training in computer. The current sample includes 37 male, 77 female students and in total 114 students. The data of the study was developed by Dal and Aktay (2015) and their "Critical literacy scale for the Internet" were used to conduct a face-to-face survey. Statistical analysis of the data was conducted using SPSS 22.0 program. Shapirowilk test was applied to check the normality distributions of numerical variables and normal distribution was obtained. In the data set, parametric tests were used. In the analysis of group differences in the averages for the descriptive statistics, independent sample t-test and one-way ANOVA test and Turkey HSD multiple comparison test was used to determine meaningful differences between groups in these outcomes. There was no significant differences between the scores of critical literacy subscales for the internet according to the age, gender, and internet among the students who participated in the study
\end{abstract}

Keywords: Internet, Social Media, Critical Literacy, Media Literacy. 


\section{Giriş}

21. yüzyılda bireylerin günlük hayatlarında yeni iletişim teknolojilerinin kullanımı oldukça önem kazanmıştır. Kamuda ve özel sektörde iletişim teknolojilerinin kullanım şekilleri, düzeyleri ve uygulamaları toplumdaki kişiler arasında toplumsal etkileşim biçimlerini değiştirmiştir. İletişim teknolojilerinden olan PC'ler, akıllı cep telefonları ile birlikte yeni iletişim teknolojileri toplum için günümüzde bir zorunluluk haline gelmiştir. Tüm bunlara bağlı olarak üstelik bu yeni iletişim araçlarının geleneksel olanlar ile yer değiştirdiği de araştırmacılar tarafından öne sürülmektedir (Aydoğan, 2009, 186).

Günümüzde internet bir araç, bir mecra olarak kullanılmaya başlanmıştır. Yönelimler ve kullanım alt yapılarının gelişmesi nedeniyle medyanın internette yer bulmaya başlamasıyla "Yeni Medya" olarak nitelendirilen bir unsur ortaya çıkmıştır. Bu yeni unsur olan "kitlesizleştirme, karşılıklı etkileşim ve eş zamansız olabilme" yönleri ile geleneksel medyadan ayrıșan yeni medya kullanımında herbir birey, katılımcı, bilginin hem tüketicisi hem de üreticisi pozisyonundadır (Ata, 2018, 835). Çünkü toplumların ihtiyaçları çerçevesinde birey nitelikleri günümüzde değişikliğe uğramıştır. Bu noktada internetin kişisel kullanıma açılması, internet tabanlı uygulamaların gelişmesi ile iletişim sürecinin doğasında da farklılıklar yaşanmıştır. Bu yeni iletişim ortamında, internet tabanlı uygulamalara yönelik kişisel kullanım pratiklerinin yanı sıra marka iletişim sürecinde de yaygınlaşmaları dikkat çekmektedir (Ulaş, 2018, 865). Bireyler teknolojinin etkisiyle sürekli gelişen ve değișen bilgi karşısında yeni teknoloji kullanımı konusunda ayrıcalıklı değil adeta zorunludurlar. Bu sebeple yeni medya ortamında yer alanların bilgiye erişim yöntemlerini bilen, ihtiyaçları dâhilinde bilgiyi kullanabilen ve yeni içerikler üretebilen yetkinlikte olmaları beklenmekledir. Bilhassa gençler yeni medyayı kolay kullanımı, hızlılığı nedeni ile daha yoğun kullanmaktadır. Ayrıca günümüzde internet, akademide ve diğer alanlarda da yoğun şekilde kullanılmaya başlanmıștır (Diker ve Taşdelen, 2017, 190).

İletişim araçlarının sayı yönünden artışı fakat diğer taraftan niteliksizleşmesi günümüz iletişim araçlarında sadece içerik çözümleme ve içerik üretebilmekten daha fazlasını gerekli kılmaktadır. Medya tarafından gönderilen bilgiler hakkında kişiler sahip oldukları bilgiler düzeyinde tehlikenin farkında olurlar. Buna bağlı olarak kişilerin medya içeriklerinin tehlikelerinden korunabilmesi, mesajları çözümleyebilmesi için eleştirel bir bakış açsına ihtiyaç vardır. Ayrıca bireylerin okuryazar olabilmesi oldukça önem arz etmektedir Karaman $(2016,327)$ da kişilerin İletişim bilimi olan; internet yolu ile gelen olumsuz içeriklere maruz kalmaması için medya okuryazarlığı becerisine sahip olmaları gerektiğini vurgulamaktadır. Çünkü teknolojinin bireylere sunduğu bir takım avantaj ve kolaylığının yanı sıra teknolojini dezavantajları da bulunmaktadır. Bilginin niteliği bu dezavantajlarından en önemli kısmıdır. Kişilerin yoğun bilgi arasında kendisini koruma hassasiyeti vardır. Fakat bu kendini koruma içgüdüsü bireylerin gerçek fayda sağlayabileceği bilgileri de kaybedebilme ihtimalini doğurmaktadır (Bawden ve Robinson, 2009).

Yeni medyanın oluşturmuş olduğu içerikler bireylerin inançları, algıları, tutumları, alışkanlıkları, tercihleri, çevrelerini algıları üzerinde oldukça etkili bir unsur olmuştur (Thoman ve Jolls, 2005; Kellner ve Share, 2007; Koltay, 2011; Arslan ve Dursun, 2017). Bunun sonucunda güvenlik, bağımlılık, zorbalık, gizlilik ihlali, kimlik hırsızlığı ve benzeri problemler meydana gelmektedir (Burnett ve Merchant, 2011). $\mathrm{Bu}$ sonuçlardan yola çıkarak bilgi ve iletişim teknolojileri ile hayatını yaşayan 
kişilerin teknolojiyi etkili ve amacı çerçevesinde kullanması oldukça mühimdir (Jones vd; 2006; Finegold ve Notabartolo, 2008; Mohammadyari ve Singh, 2015; Ainley vd, 2016; Arslan ve Candan, 2017). Karasu ve Arıkan $(2016,549)$ aksi takdirde enformasyonun kısa süreler içinde yayıldığı günümüz şartlarında doğruluğu, güvenilirliği kanıtlanmamış propaganda niyetli ortaya atılan bilgiler olarak toplum ve bireyler nezdinde olumsuz sonuçlara neden olabilmektedir. Çubukçu ve Bayzan (2013) Yaşanan teknolojik gelișme ve değişimler göz önüne alındığında, günümüz dünyasında kişilerin güvenli bilgiye, kaynağa ulaşması, güvenli internet kullanması için bilinçli internet kullanımı ve dijital okuryazarlık önemli unsurlardandır. Yapılan literatür taramasında da dijital okuryazarlık ile ilgili çalışmalar (Prior vd, 2016; Radovanović vd, 2015; Özbay ve Özdemir, 2014; Sönmez ve Gül, 2014; Tüzel ve Tok, 2013; Çubukçu ve Bayzan, 2013) araştırmacılar tarafından yapılmıştır.

Yeni medya okuryazarlığı kişilerin çevrimiçi olanaklardan yararlanırken, çevrimiçi risklere karşı da bilgili, donanımlı olmasını sağlar ayrıca çevrimiçi olanaklardan da en etkin şekilde yararlanmasının yolunu açar. Eleştirel okuryazarlığın diğer anlamı analitik okuma yapmaktır. İçeriğe maruz kalan kullanıcının bu herhangi bir mesajı aldığında o mesaj içeriğin niçin oluşturulduğu, ne söylemek istediği, kimi kapsadığı, mesaj ayrım yapmakta olup olmadığı sorularını kendine sorar ve bu şekilde tamamını bir bütün şeklinde değerlendirir (Gregory ve Cahill, 2009). Eleştirel okuryazarlık temelde okuryazarlığı öğrenmeye yönelik bir eylemdir (McLaughlin ve DeVoogd, 2004). Eleştirel okuryazarlık felsefe olarak mesajı üretenlerden gelen içeriklerin tamamının doğru olmadığı, tarafsız olmadığı büyük bir çoğunluğunun yazarın bakış açısı ile üretildiğinin farkında olmasıdır.

İnternet teknolojisinin hayatımızın merkezinde yer almaya başlaması, kayıtsız kalınamayacağı gerçeğini doğurmakla birlikte; dijital okuryazarlık konusunda çalışmayı gerekli kılmaktadır. Dal ve Aktay (2015) tarafından geliştirilen internet için eleştirel okuryazarlık ölçeği, kullanılarak yapılan bu çalışma hem üniversite öğrencilerinin eleştirel okuryazarlık düzeylerinin tespit edilmesi hem de sahip oldukları eleştirel bakış açısının geliştirilmesi hedeflenmektedir. Bu çalışma ile amaçlanan internet okuryazarlık yetkililiğinin kazanılmasının bilgi çağındaki toplumlar için mecburi bir davranış şekli olduğunun bilimsel yöntemlerle vurgulamaktır. Aynı zamanda bu alanda çalışma yapacak araştırmacıların veri ihtiyacının karşılanması ve alan yazınına katkı sağlama amacını taşımaktadır.

\section{Yeni Medya Kavramı ve Bilgi Toplumu}

İçinde bulunduğumuz bilgi iletişim toplumunda, küresel döngü ve iletişim teknolojilerinde yaşanan değişimler iletişim politikalarında yenilenmeyi de beraberinde getirmektedir. Buna bağlı olarak geleneksel medyadan farklı olarak yeni medya kavramı meydana gelmiştir (Mutlu, 2004, 311). Yeni medyayı geleneksel medyadan ayıran en temel özelliklerinden birisi ileri ve dijitalleşmiş olmasıdır. Bunlar akıllı cep telefonlarımız, bilgisayarlarımızdır (Çiftçi, 2018, 422). Geleneksel medya olarak isimlendirilen medya televizyon, radyo, gazete ve benzeri kitle iletişim araçları ile gerçekleşen iletişim sürecinde kaynak ve alıcı arasında gerçekleşen ileti üzerinde karşılıklı etkileşime dayalı bir süreç oluşmamaktadır. Fakat geleneksel medyaya karşın yeni medya karşılıklı etkileşim, iletişim olanaklarına sahiptir. Kaynak alıcı olabilirken alıcı da kaynak olabilmektedir. İleti üzerinde alıcının da denetimi yüksek düzeyde olabilir. Bu nedenle herhangi başka bir araca gereksinim yoktur. Aynı zamanda yeni medya büyük gruplar içerisinde bir kişi ile dahi özel ileti alışverişi 
yapabileceğini oluşturacak derecede kitlesizleștirebilir. Buna bağlı olarakyeni medya, aynı bulunma mecburiyetini ortadan kaldırabilen eş zamansız olabilme özelliğine sahiptir. Tüm bu unsurlara bakarak, yeni medya, kitle izleyicisini toplumsal olarak kapsamanın yanı sıra bireyi kullanıcı şeklinde de kapsayabilen, kullanıcı gruplarının içeriğe ya da uygulamalara değişik zamanlarda etkileşimde bulunabildikleri ortamlardır (Geray, 2003, 7; Çiftçi, 2018, 888). ASPEN medya okuryazarlık enstitü üyeleri, medya okuryazarlığını medya ile ilişki (giriş), değerlendirme, yeni içerik yaratma becerisi şeklinde tanımlamışlardır. Potter (2004) medya okuryazarlığını birey algısı olarak tanımlamanın yanı sıra; medya okuryazarlığını hem geleneksel hem de yeni medya okuryazarlığı olarak tanımlamaktadır. Bir bireyin bilgisayarı kullanabilmeyeteneğine ek olarak onun teknikaksaklıkları da giderebilme beceresine sahip olması teknolojinin toplumu nasıl etkilediği gerçeğini ispatlamaktadır.

\section{Eleştirel Bakış ve Medya Okuryazarlığı}

Çağımızın bilgi iletişim dünyasında eleştirel düşünce şekli özgün bir beceri olsa bile medya okuryazarlığı ilekuvvetli bir bağıvardır. Günümüzün enönemliözelliklerinden birisi bilgi üretiminin, dağıtımının ve tüketiminin hızlı bir şekilde teknolojik araçlarla yapılmasının yanı sıra bu teknolojilerin gösterdiği hızlı gelişimdir (Pérez Tornero ve Varis, 2010; Kellner ve Share, 2007). Bu teknolojik değişim ve dönüşüm toplumda bireyin toplumsal, sosyal, mesleki, ekonomik, kişisel, akademik alışkanlıklarında değişiklikler meydana getirmiştir. Bu nedenle bireyin günümüzdeki ve geçmişteki bilgi ve becerileri birbirinden ayrışmaktadır (Ananiadou ve Claro, 2009). Okurların medya karşısındaki konumu da medya gerçekliği konusunda önem arz etmektedir. Liberal bakış açısına gere hedef kitle pasiftir; verilen her iletiyi irdelemeden alır. Fakat eleştirel yaklaşımcılara göre ise hedef kitle sorgulayan, geri dönüt yapan, verilen mesajın içeriğinde kültür ve toplum değerlerinin de varlığının bilincindedir. Alıcılar içerikte gönderilen mesajları gönderildikleri şekli ile mi kabul edecekler yoksa sahip oldukları çevrelerinin de gerçekliklerini katarak anlamaya çalışacaklar? Sorusu eleştirel yaklaşımlarda cevap bulmaktadır (Ata, 2018, 835).

Literatür taramasında birçok araştırmacının eleştirel düşünme kavramı ile ilgili farklı görüşleri vardır. Eleștirel düşünme bilincin kullanılması ile yapılan bilișsel bir davranıştır. Eleştirel düşünce herhangi bir konuda sorgulama ve kabul etmeyi olumlu yönde kullanabilmek için iddaa ve kanıtların geliştirilmesini sağlamaktadır (Cottrell, 2005, 35; Facione 1990, 4; Ennis, 1996, 166). Paul da bilgi ve gözlem vasıtası ile neticeye ulaşmayı eleștirel düșünce olarak kabul etmiștir (Paul, 1991, 124). Eleștirel düşünce; 1990'da American Psychological Association (APA)'nın 46 akademisyen ile gerçekleștirdiği çalışmada ortak tanım olarak " Kişilerin yapmak ve inanmak istedikleri, karar verme sürecinde kritik yapma isteği ile değerlendirmeler yapılması ve bu değerlendirmelerin açığa çıkması" şeklinde belirlemiştir(Evancho, 2000, 25). Her ne kadar eleştirel düşünce tanımı farklılaşma gösterse de eleştirel düşüncenin hadiselerin, fikirlerin olumsuzluklarını görmek ve bu bakış açısına dayanarak eleştirmek değildir. Amaç olayların, fikirlerin aktarılırken kanıtlarla ifade edilmesidir.

Medya okuryazarlığı son zamanlarda iletişim biliminde önem kazanmaya başlamıştır (Güngör, 2013, 357). Medya okuryazarlığı farklı biçimdeki bilgileri analiz, açıklama ve yeniden oluşturma becerisidir (Ofcom Media Literacy Bulletin, 2006: Kellner ve Share, 2005, 369; Thoman ve Jolls, 2008, 151; Hoem, 2004, 3). Başka bir ifadeye göre medya okuryazarlığı kişilerin medya araçlarına, iletilerine maruz kalma şeklini, 
mesajları anlayabilme, yorum yapabilme yeteneğidir (Potter 2004, 42). Bu yetenek yüksek ve düşük olarak değerlendirilebilir. Düşük düzey medya okuryazarlığının kişilerin aleyhinedir. Sevim (2013)'e göre medya okuryazarlığı diğer okuryazarlık çeşitlerinden farklı olarak yalnızca bilginin bilinçli kullanılmasını değil; aynı zamanda bilgi kullanımını sınırlayabilme becerisini öğretmektedir (Sevim, 2013).

Silverblatt ve Elicieri (1997)'e göre kişilerin medyadan gelen mesajların içeriklerini anlamalarına, çözmelerine yardımcı olan aynı zamanda medya içerikleri konusunda fikir geliştirmesini sağlayan eleștirel düşünme kabiliyetidir (Akt. Potter, 2010). Alanyazı incelendiğinde bilgi çağındaki süreçte başarılı olabilmek için eleştirel düşünceye ve medya okuryazarlık konusunda becerili olmak zorunluluktur (Salpeter, 2008; Wagner, 2008; Trilling ve Fadel, 2009).

Eleştirel düşünce ve medya okuryazarlığı ilişkisi konusunda yapılan çalışmalar incelendiğinde (Masterman, 2005; Dubey vd., 2016; Erdem, 2018; Silverbaltt vd., 2014; Mkandawire ve Walubita, 2015; Steinbrink ve Cook, 2003) eleştirel düşünce eğitimi ile medya okuryazarlığı eğitiminin birlikte verilmesi, birbirinden ayrıștırılamayacağı gerekliliği vurgulanmaktadır. Bunun temel sebebi eleştirel düşünce yapısını esas alan medya okuryazarlığı eğitimi kişilere medya mesajlarını eleştirel irdelemesine, doğru ve yanlış arasındaki farklılıkları tespit etmesine imkân sağlamaktadır (Scull ve Kupersmidt, 2012; Leon, 2016; DeAbreu, 2010). Buna dahil olarak son dönemlerde eleştirel medya okuryazarlığı ve muhalif medya çerçevesinde trol kültürü de çalışılmaya başlanmıştır. Trol kültürü ve trol davranışlarının yeni medyanın yeniliğiyle birlikte kullanıcılara eleştirel yaklaşımlarında mizah ortamı da sunduğunu açıktır (Çiftçi ve Evren, 2018)

Medya okuryazarlığı; teknoloji okuryazarlığı, bilgi okuryazarlığı, bilgisayar okuryazarlığı, internet okuryazarlığı ile benzeri okuryazarlık dalları alakalıdır. Medya okuryazarlık eğitimleri eğitim ve öğretimin ilk yıllarında verilmeye başlanmalıdır. Buna bağlı olarak bireye medya okuryazarlık ile eleștirel bakıș açısının kazandırılması sorumluluğu eğitim kurumlarındadır. Medya okuryazarlığı hem öğretmen hem de öğrencilere eleștirel bakıș açısı ile bakmanın avantajlarını sunar. Öğretmenler, öğrencilere interneti yararlarına uygun olarak nasıl kullanacaklarını, internetin zararlarından nasıl korunacakları konusunda rehber olmalıdırlar (Schwarz, 2001, 117). Eğitim kurumlarında görev yapan öğretmenlerin bu bakış açısını kazandırmaları, örnek olabilmeleri için öncelikle kendilerinin eğitim almaları gerekli kılmaktadır (Altun, 2009; Considine, 2002; Redmond, 2016; Karaman ve Karataş, 2009; Domine, 2011; Fleming, 2013; Jolls ve Grande, 2005; Recepoğlu, 2015; Som ve Kurt, 2012; Hobbs, 2010).

\section{Araştırmanın Amacı ve Önemi}

$\mathrm{Bu}$ araștırmanın temel amacı, Meslek Yüksekokulu öğrencilerinde internet için eleştirel okuryazarlık düzeylerini karşılaştırmalı şekilde incelemektir. Bu temel amaç doğrultusunda;

1. Meslek Yüksekokulu öğrencilerinin internet için eleştirel okuryazarlık düzeyleri ne seviyededir?

2. Meslek Yüksekokulu öğrencilerinin cinsiyet değişkenine göre internet için eleştirel okuryazarlık düzeylerindeanlamlı bir fark var mıdır? 
3. Meslek Yüksekokulu öğrencilerinin yaş grupları arasında internet için eleştirel okuryazarlık düzeylerinde anlamlı bir fark var mıdır?

4. Meslek Yüksekokulu öğrencilerinin sınıf düzeyleri arasında internet için eleștirel okuryazarlık düzeylerinde anlamlı bir fark var mıdır?

5. Meslek Yüksekokulu öğrencilerinin internet kullanım sıklığı arasında internet için eleştirel okuryazarlık düzeylerindeanlamlı bir fark var mıdır?

Ayrıca çalıșma üniversite öğrencilerinin hem eleștirel okuryazarlık düzeylerinin tespit edilmesi hem de sahip oldukları eleştirel bakış açısının geliştirilmesinin tespit edilmesini amaçlar. Buna ek olarak internet okuryazarlık becerisinin kazanılmasının bilgi çağındaki toplumlar için mecburi bir davranış şekli olduğunun bilimsel yöntemlerle yöneticilere ispat edilmesi konusunda büyük önem taşımaktadır. $\mathrm{Bu}$ çalışma ile amaçlanan aynı zamanda bu alanda çalışma yapacak araştırmacıların veri ihtiyacının karşılanması ve alan yazınına katkı sağlama amacını taşımaktadır.

\section{Araştırmanın Sınırlııkları}

1. Araştırma bulguları anketin uygulandığı Meslek Yüksekokulu'ndaki öğrencilerin 10-30 Eylül 2018 zaman dilimindeki internet için eleştirel okuryazarlık düzeylerini belirlemektedir.

2. Anket öğrencilerin internet eleştiri düzeylerinin ölçmeye yönelik olduğundan; isimlerinin alınmamasına rağmen öğrenciler; İnternet kullanım oranlarının, eleştirel bilgi düzeylerinin ölçüleceği endişesi ile ankete yoğun katılım göstermemişlerdir.

3. Araştırma verilerinin yalnızca anket yapılarak elde edilmesi gözlem, mülakat vb. yöntemlerinin kullanılmaması araştırmanın bir diğer sınırlılığıdır.

4. Zaman ve maliyet açısından bu araştırma, Gaziantep Üniversitesi Teknik Bilimler Meslek Yüksekokulu Bilgisayar Programcılığında eğitim gören 37 erkek, 77 kız toplam 114 öğrenci ile sınırlıdır. İnternetin kullanım oranlarının arttığı günümüzde başka üniversitelerde, farklı bölümlere, Milli Eğitim okullarında da (İlköğretim, Ortaokul, Lise) anketin uygulanması alana katkıda bulunabilir.

5. Çalışma Gaziantep Üniversitesi Teknik Bilimler Meslek Yüksekokulunda yapıldığından örneklem grubunu 1. ve 2. sinıflar oluşturulmuştur. Çalışmanın sadece Meslek Yüksekokulu'nda yapılması, araştırmada sınıf düzeyi bağlamında bir farklılaşma bulunmaması, örneklemin yalnızca birinci ve ikinci sınıf öğrencilerinden oluşmasından kaynaklanmıș olabilir. Bu nedenle araștırma daha sonra fakültelerin 1.2.3.4. sınıflarında öğrenim görenlere uygulanabilir.

\section{Araştırmada Kullanılan Veri Analiz Tekniği}

Araştırmanın verileri Dal ve Aktay (2015) tarafından geliştirilen "İnternet için Eleştirel Okuryazarlık Ölçeği" kullanılarak yüz yüze anket tekniği ile gerçekleştirilmiştir. Anketörün cevaplayıcı ile iletişime geçtiği yüz yüze anket en güvenilir veri toplama yöntemleri arasında yer almaktadır (Gültekin ve Arslan 2018, 266). Çalışmanın istatistiksel analizleri SPSS 22.0 programı kullanılarak yapılmıştır. Sayısal değişkenlerin normallik dağılımlarına bakmak için shapirowilk testi uygulanmış ve normal dağılım elde edilmiştir. Veri setinde parametrik testler kullanılmıştır. Tanımlayıcı istatistiklerin çözümlenmesinde de frekans, yüzde, aritmetik ortalama, standart sapma, minimum ve maksimum değerlerden faydalanılmıştır. Ölçekler normallik dağılımına uygun olduğundan, bağımsız 2 
grubun ortalama karşılaştırılmasında bağımsız örneklem t testi, 2'den fazla bağımsız grubun karşılaştırılmasında ise One-WayANOVA (Varyans Analizi) testi, gruplar arasındaki farklılıkları Tukey HSD çoklu karşılaştırma testi kullanılmıștır. Sonuçlar \%95'lik güven aralığında, 0,05 anlamlılık düzeyinde değerlendirilmiștir. Ayrıca ölçek ve alt boyutları için güvenilirlik analizi yapılmış ve güvenirlik katsayısız Cronbach'salpha olarak elde edilmiştir.

\section{Araştırmanın Evreni ve Örneklemi}

Araştırmanın evrenini 2018-2019 eğitim-öğretim yılında Gaziantep Üniversitesi Teknik Bilimler Meslek Yüksekokulu Bilgisayar Programcılığında eğitim gören öğrenciler oluşturmaktadır. Örneklemini ise 37 erkek, $77 \mathrm{klz}$ toplam 114 öğrenci oluşturmaktadır. Araştırmacılar 250 evrenli topluluktan örneklem büyüklüğü 0,05 hata payı ile seçerken 114 kişinin yeterli olduğunu belirtmiştir (Balcl, 2011, 106). Anketin Bilgisayar programı öğrencilerine uygulama nedenleri; Bilgisayar Programında; Yeni Medya, Sosyal Medya, Kitle İletişim, Bilgi Okuryazarlık ve benzeri dersleri öğrencilerin görüyor olmasıdır. Cinsiyet oranlarına bakıldığında; ankete katılan öğrencilerden 37'sini erkekler, 77'sini kızlar oluşturmaktadır. Araştırmaya çoğunlukla 18-24 yaş grubu arasındaki öğrenciler katılım göstermiştir. Katılımda gönüllülük esası temel alınmıştır. Çalışmaya katılanlardan kişisel bilgileri istenmemiştir.

\section{Araştırmada Kullanılan Veri Toplama Tekniği}

Araştırmada "İnternet İçin Eleştirel okuryazarlık Ölçeği", üniversite öğrencilerinin internet için eleştirel okuryazarlığı ölçebilmek üzere Dal ve Aktay (2015) tarafından geliştirilmiştir. İnternet için eleştirel okuryazarlık toplam 27 maddeden, tek alt boyuttan oluşmaktadır. Veriler meslek yüksekokulu öğrencilerine yüz yüze anket yöntemiyle toplanmıştır. Araştırmada nicel yaklaşımlardan anket veri toplama tekniği kullanılarak veriler elde edilmiștir. Hazırlanan anket formu, internet bağlamında bireylerin okuryazarlık düzeylerinin tespit edilmesine yönelik olarak, kişilerin eğilim veya davranışlarını sergileme sıklığını tespit etmeye yönelik toplam 27 soruluk tek faktörden oluşmaktadır. Ölçekte yer alan ifadeler "1: Hiçbir zaman", "2: nadiren”, “3:ara sıra”, “4:çoğunlukla”, “5: her zaman” şeklinde 5’li Likert tipi ölçekle ölçümlenmiştir. Çalışmada faydalanılan ölçek yazarlar tarafından geliştirildiğinden 449 kişi ile ön teste tabi tutulmuştur. Araştırma sonucunda elde edilen Cronbach Alpha güvenirlik değeri ise 0,950 olarak belirlenmiştir. Yine alfa katsayına bağlı olarak ölçeğin yüksek derecede güvenilir olduğu söylenebilir (Kalaycı, 2006).

\section{Bulgular}

Tablo 1: Sosyo-Demografik Dağılım

\begin{tabular}{|l|c|c|}
\hline Cinsiyet & n & \% \\
\hline Erkek & 37 & 32,5 \\
\hline Kız & 77 & 67,5 \\
\hline Yaş & & \\
\hline 18-24 arası & 106 & 93,0 \\
\hline 25 ve üzeri & 8 & 7,0 \\
\hline Sınıf & & \\
\hline 1.sınıf & 63 & 55,0 \\
\hline 2.sınıf & 51 & 45,0 \\
\hline
\end{tabular}


Araștırmaya katılan öğrencilerin \%32,5'i erkek, \%67,5'i kız; \%93'ü 18-24 yaș arasında, \%7'si 25 yaş ve üzerinde; \%55'i 1.sınıf, \%45'i ise 2.sınıftadır.

Tablo 2: Internete En Çok Bağlanılan Yerler, İnternet Erişim Araçları ve Internet Kullanım Amaçları Dağılımı

\begin{tabular}{|l|c|c|}
\hline İnternete bağlanııma yeri & $\mathbf{n}$ & $\%$ \\
\hline Evden & 8 & 7,0 \\
\hline Okuldan & 11 & 10,0 \\
\hline Cep telefonundan & 108 & 95,0 \\
\hline İnternet kafeden & 3 & 3,0 \\
\hline Diğer & 1 & 1,0 \\
\hline İnternet erişim araçları & $\mathrm{n}$ & $\%$ \\
\hline Bilgisayar/laptop & 20 & 18,0 \\
\hline Cep telefonu & 109 & 96,0 \\
\hline Tablet & 7 & 6,0 \\
\hline İnternet kullanım amaçları & $\mathrm{n}$ & $\%$ \\
\hline Haber okumak için & 40 & 35,0 \\
\hline Bilgi erişimi için & 94 & 83,0 \\
\hline Eğlence, oyun vb. için & 46 & 40,0 \\
\hline Video, fotoğraf yüklemek için & 32 & 28,0 \\
\hline Boş zaman değerlendirmek için & 29 & 25,0 \\
\hline Sosyal ağlara katımak için & 54 & 47,0 \\
\hline Alşsveriş için & 22 & 19,0 \\
\hline
\end{tabular}

Araştırmaya katılan öğrencilerin en çok internete sırasıyla cep telefonu (\%95), okuldan (\%10) ve evden (\%7) bağlandıkları; öğrenciler en çok cep telefonu (\%96), bilgisayar/laptop (\%18) ve tablet kullanarak internete erişim sağladıkları görülmektedir. Ayrıca öğrenciler interneti sırasıyla bilgi erişimi (\%80), sosyal ağlara katılmak (\%47), eğlence, oyun vb. aktiviteleri kullanmak (\%40) için kullandıklarını belirtmişlerdir.

Tablo 3: Internet Kullanım Siklığı

\begin{tabular}{|l|c|c|}
\hline İnternet kullanım sıklığı & $\mathbf{n}$ & $\mathbf{\%}$ \\
\hline Günde 1 saat & 9 & 7,0 \\
\hline Günde 1-3 saat arası & 23 & 20,0 \\
\hline Günde 3-5 saat arası & 41 & 36,0 \\
\hline Günde 5 saat ve üzeri & 41 & 36,0 \\
\hline
\end{tabular}

Araștırmada öğrencilerin \%7'si interneti günde 1 saat, \%20'si günde 1-3 saat arasında, \%36'sı günde 3-5 saat arasında ve \%36'sı ise günde 5 saat ve üzerinde kullandıklarını belirtmişlerdir.

Tablo 4: Sosyal Medya Bağımlılık Alt Boyutları ve İnternet İçin Eleştirel Okuryazarlık Ölçeği Tanımlayıcı İstatistikleri

\begin{tabular}{|l|c|c|c|c|}
\hline Ölçek & n & Ort. & S.S. & Min.-maks. \\
\hline Eleştirel okuryazarlık & 114 & 83,57 & 21,06 & $35-135$ \\
\hline
\end{tabular}

Araştırmada internet için eleştirel okuryazarlık ortalama puanı 83,57'dir ve puan değerlendirildiğinde; öğrenciler internet için eleştirel okuryazarlık düzeyi ortalamanın üzerinde olarak görülmektedir. 
Tablo 5: Internet İçin Eleștirel Okuryazarlık Ölçeği Güvenilirlik Analizi

\begin{tabular}{|l|c|c|}
\hline Ölçek & Madde sayısı & Cronbach'salpha \\
\hline İnternet İçin Eleştirel okuryazarlık & 27 & 0,960 \\
\hline
\end{tabular}

Kullanılan ölçeklerin ve alt boyutlarda yer alan maddelerin güvenirlilik analizleri için Alpha modeli ile maddeler arası korelasyona bağlı uyum değerleri hesaplanmıştır. Alfa $(\alpha)$ katsayısına bağlı olarak ölçek ve alt boyutlarının güvenirliliği aşağıdaki gibi değerlendirilmiştir.

$0.00 \leq \alpha<0.40$ ise ölçek/boyut güvenilir değildir,

$0.40 \leq \alpha<0.60$ ise ölçeğin/boyutun güvenilirliği düşük,

$0.60 \leq \alpha<0.80$ ise ölçek/boyut oldukça güvenilir, ve

$0.80 \leq \alpha<1.00$ ise ölçek/boyut yüksek derecede güvenilirdir (Kalaycl, 2006: 405).

İnternet için eleştirel okuryazarlık ölçeği $(\alpha=0,960)$ için hesaplanan güvenirlik katsayısı, yüksek derecede güvenilirdir.

Tablo 6: Internet İçin Eleştirel Okuryazarliğına Göre Cinsiyete Göre Karşılaştırılması

\begin{tabular}{|l|c|c|c|c|}
\hline \multirow{2}{*}{ Cinsiyet' } & \multicolumn{2}{|c|}{$\begin{array}{c}\text { Eleştirel } \\
\text { okuryazarlı }\end{array}$} & \multirow{2}{*}{ t } & \multirow{2}{*}{ p } \\
\cline { 2 - 3 } & Ort. & S.S. & & \\
\hline Erkek & 83,27 & 17,36 & \multirow{2}{*}{$-0,105$} & 0,917 \\
\hline Kız & 83,71 & 22,73 & & \\
\hline${ }^{1}$ Bağımsız Örneklem t testi & & \\
\hline
\end{tabular}

Araştırmada internet için eleştirel okuryazarlık düzeyleri cinsiyetler arasında farklılık göstermemektedir (t:-0,105; p:0,107>.05).

Tablo 7: İnternet İçin Eleştirel Okuryazarlığın Göre Yaş Gruplarına Göre Karşılaştırılması

\begin{tabular}{|l|c|c|c|c|}
\hline \multirow{2}{*}{ Yaş grupları' } & \multicolumn{2}{|c|}{$\begin{array}{c}\text { Eleştirel } \\
\text { okuryazarlık }\end{array}$} & \multirow{2}{*}{ t } & \multirow{2}{*}{ p } \\
\cline { 2 - 3 } & Ort. & S.S. & & \\
\hline $18-24$ arası & 82,60 & 20,05 & \multirow{2}{*}{$-1,801$} & 0,074 \\
\hline 25 ve üzeri & 96,38 & 30,54 & & \\
\hline \multicolumn{2}{|l}{ 'Bağımsız Örneklem t testi } \\
\hline
\end{tabular}

Araştırmada 25 yaş ve üzerindeki meslek yüksekokulu öğrencilerinin ortalama eleştirel okuryazarlık puanı, 18-24 yaşındaki öğrencilerin puanından yüksek ancak aralarındaki fark anlamlı değildir (t:-1,801; p:0,074>.05).

Tablo 8: Internet İçin Eleștirel Okuryazarlığın Göre Sınıf Düzeylerine Göre Karşılaştırılması

\begin{tabular}{|l|c|c|c|c|}
\hline \multirow{2}{*}{ Sınıf düzeyleri' } & \multicolumn{2}{|c|}{ Eleştirel okuryazarlık } & \multirow{2}{*}{ t } & \multirow{2}{*}{ p } \\
\cline { 2 - 3 } & Ort. & S.S. & & \\
\hline 1.sınıf & 81,24 & 21,73 & \multirow{2}{*}{$-1,318$} & \multirow{2}{*}{0,190} \\
\hline 2.sınıf & 86,45 & 20,04 & & \\
\hline 'Bağımsız Örneklem t testi & & \\
\hline
\end{tabular}

Araştırmada 2.sınıf öğrencilerinin ortalama eleștirel okuryazarlık puanı, 1.sınıf öğrencilerinden daha yüksek bulunmuş ancak aralarındaki fark anlamlı değildir (t:1,318; p:0,190>.05). 
Tablo 9: İnternet İçin Eleştirel Okuryazarlığın Göre İnternet Kullanım Sıklıklarına Göre Karşıllaştırılması

\begin{tabular}{|l|c|c|c|c|}
\hline \multirow{2}{*}{$\begin{array}{l}\text { İnternet kullanım } \\
\text { sıklığı1 }\end{array}$} & \multicolumn{2}{|c|}{$\begin{array}{c}\text { Eleştirel } \\
\text { okuryazarlık }\end{array}$} & \multirow{2}{*}{ F } & \multirow{2}{*}{ p } \\
\cline { 2 - 3 } & Ort. & S.S. & & \\
\hline Günde 1 saat & 90,78 & 12,29 & & \\
\hline Günde 1-3 saat arası & 76,26 & 20,70 & \multirow{2}{*}{1,84} & \multirow{2}{*}{0,144} \\
\hline Günde 3-5 saat arası & 82,20 & 19,16 & & \\
\hline Günde 5 saat ve üzeri & 87,46 & 23,67 & & \\
\hline 1One-way ANOVA testi & & & \\
\hline
\end{tabular}

Araştırmada Meslek Yüksekokulu öğrencilerinin internet için eleştirel okuryazarlık puanı, internet kullanım sıklıkları arasında anlamlı değildir (F:1,840; p:0,144>.05). Bununla birlikte internet için eleştirel okuryazarlık puanı en yüksek grup, interneti günde 1 saat kullanan öğrenciler olarak görülmektedir.

\section{Tartışma ve Sonuç}

$\mathrm{Bu}$ araştırmada Meslek Yüksekokulu öğrencileri arasında internet için eleştirel okuryazarlık düzeyleri incelenmesi amaçlanmıştır. Araştırmaya katılan Meslek Yüksekokulu öğrencilerinin internet için eleştirel okuryazarlık puanları sırasıyla cinsiyet, yaş grupları, internet kullanım sıklığı değişkenleri bakımından farklılık oluşturup oluşturmadığına ilişkin bulgulara yer verilmiştir.

Araștırmaya katılan meslek yüksekokulu öğrencilerinden, 37 kişi $(\% 32,5)$ erkek, 77 kişi $(\% 67,5)$ ise kız öğrencileri olduğu; meslek yüksekokulu öğrencilerinin \%93'ü1824 yaş grubu arasında yer almakta; öğrencilerin \%55'i 1 .sınıf ve \%45'i ise 2.sınıftadır. Meslek Yüksekokulu öğrencileri internete hem erişim (\%96) hem de bağlanma yeri (\%95) olarak en çok cep telefonundan bağlanmaktadır. Ayrıca öğrenciler interneti en fazla bilgi erișimi (\%83), sosyal ağlara katılım (\%47) ve eğlence, oyun vb. aktiviteleri (\%40) kullanmaktadır. Meslek Yüksekokulu öğrencilerinin \%72'si günde en az 3 saat interneti kullanmakta olup bununla birlikte internet kullanmayan öğrenci yoktur.

Araştırmaya kapsamında elde edilen bulgulara göre araştırma örneklemini oluşturan Meslek Yüksekokulu öğrencilerinin internet için eleştirel okuryazarlık puanları cinsiyet açısından anlamlı bir fark gösterip göstermediği incelendiğinde; "Erkek öğrencilerin eleștirel okuryazarlık puanı ile kız öğrencilerin puanı arasında farklılık görülmemiştir". Bu bulgular Som ve Kurt, 2012; Sarsar ve Engin, 2015; Korkmaz, 2009; Fidan, 2013; Ata ve Baran, 2011; Piji Küçük ve Uzun, 2013; Korkut ve Akkoyunlu, 2008; Şen, 2009; Akaydın ve Kurnaz, 2015; Çepni vd; 2015; Yılmaz ve Aladağ, 2015; Karasu ve Arıkan, 2016. Bulguları ile örtüşmektedir. Cinsiyetlerine göre Uslu vd; 2016 yaptığı çalışmada erkekler lehine farklılaştığını; Beşoluk ve Önder, 2010; Demiralay, 2008 'in yaptıkları çalıșmalarda ise kadınlar lehine farklılaştığını ortaya koyan araştırma bulgularıyla örtüşmemektedir.

Araştırmaya katılan Meslek Yüksekokulu öğrencilerinin internet için eleştirel okuryazarlık puanları, yaş grupları arasında anlamlı farklılık göstermemiştir. Araștırma kapsamında elde edilen bir diğer sonuç örneklemi oluşturan Meslek Yüksekokulu öğrencilerinin sınıf düzeylerindeki internet için eleştirel okuryazarlık düzeylerinin; "2.sınıf öğrencilerinin, 1.sınıflara göre eleştirel okuryazarlığı daha fazla ancak aralarındaki bu farklılık istatistiksel açıdan anlamlı değildir”. Bu sonuç Dinçer, 2017; Karaman, 2016; Akaydın ve Kurnaz, 2015; Çepni vd; 2015; Uslu vd, 2016 
araştırmasında elde edilen sonuç ile örtüşmektedir. Öte yandan medya okuryazarlığı becerisinin sınıf düzeyine göre farklılaştığını ortaya koyan (Korkmaz, 2009; Som ve Kurt, 2012; Güven, 2014) araştırma bulguları ile örtüşmemektedir. Çalışmanın sadece meslek yüksekokulunda yapılması, araştırmada sınıf düzeyi bağlamında bir farklılaşma bulunmaması, örneklemin yalnızca birinci ve ikinci sınıf öğrencilerinden oluşmasından kaynaklanmış olabilir.

Araştırmaya katılan Meslek Yüksekokulu öğrencilerinin interneti kullanma sürelerine göre internet için eleştirel okuryazarlık alt boyutları puanları arasında anlamlı bir fark bulunmamıștır. İnterneti az kullanan ya da çok kullanan öğrencilerin eleştirel okuryazarlıkları arasında istatistiksel açıdan anlamlı bir fark yoktur.

Sonuç olarak Meslek Yüksekokulu öğrencilerinin internet için eleştirel okuryazarlık düzeyleri sosyo-demografik özellikler ve internet kullanım sıklıkları arasında farklılık göstermemiştir. Meslek Yüksekokulu öğrencilerinin ortalama eleștirel okuryazarlık düzeyleri $(83,57)$ ortalamanın üzerindedir. Aynı şekilde Sönmez ve Gül (2014) de kişilerin karşılaştıkları dijital sorunları çözebilmeleri için okuryazarlık düzeylerinin yüksek olması gerektiği sonucuna ulaşmıștır. Okuryazarlık düzeyinin yüksek olması eleştiri becerisine de olumlu yönde etki etmektedir.

Teknolojinin gelişmesi ve akıllı telefonların ceplere kadar inmesi ile birlikte internet kullanımı kişi ve kullanım süreleri bazında artış içerisindedir (Çiftçi, 2018: 1560). Gelişen ve çeşitlenen dijital medya ortamlarında gelinen noktada dijital medya ortamları konusunda farkındalık düzeyi yüksek bireylerin etkin rol alması, kitle iletişim araçlarına ilişkin bilincin oluşması, içeriklerin doğru anlamlandırılması ve eleştirel bakış açısıyla yorumlanması büyük önem taşımaktadır.

Eleştirel dijital okuryazarlık, yalnızca çevrimiçi içerikleri anlamak ve değerlendirmek demek değildir. Dijital eleştirel okuryazarlık, internetin üretimden ve tüketime kadar gerçekleşen tüm süreçlerini, demokratikleştirme potansiyelini ve yapısal sinırlılıklarını anlamakla alakalıdır.

Eleştirel okuryazarlık, üretilen olumsuz içeriklerden korunmak amacı ile toplumdaki tüm yaş gurubundaki insanların eleştirel okuryazarlığı bilmesi gerekmektedir. Buna bağlı olarak, eleştirel internet okuryazarlığı tüm yaş grubundaki kişilerin katılımını desteklemesi ve sivil ve politik güçlenmeyi sağlaması açısından önem taşımaktadır.

Eleştirel internet okuryazarlığı bize günlük meselelerle ilgili eleştirel düşünmemizi ve kurumsal veya kurumsal olmayan politikayla ilişki kurmamızı sağlayabilir.

Toplumdaki kamu sektörleri, özellikle eğitim sektörü, eleștirel dijital okuryazarlığa bütüncül bir bakış açısı kazandırmak ve bunu desteklemek gibi bir sorumluluğu vardır. Buradaki temel amaç, dijital teknolojilerin dolayımı sayesinde sosyal ve demokratik katılıma katkı sağlamaktır.

Tüm yaş gurubundaki insanların okuryazarlık eğitimine ihtiyacı vardır. Özellikle içinde bulunduğumuz dijital çağda sorumluluk yalnızca yöneticilere, gazetecilere, uzmanlara veya birtakım kurumlara ait değildir. Görev ve sorumluluk eğitimcilere, ailelere de düşmektedir. Bu sorumluluk bilincinin de kazdırılması için gerekli eğitimler büyük önem taşımaktadır. 


\section{Kaynakça}

Ainley, J., Schulz, W. ve Fraillon, J. (2016). A Global Measure of Digital and ICT Literacy Skills. Paris: Unesco.

Akaydın, Ş. ve Kurnaz, H. (2015). Türkçe Öğretmen Adaylarının Medya Okuryazarlık Düzeyleri. V. Coşkun vd. (Editörler) Türkçe'nin Eğitim-Öğretimine Yönelik Çalışmalar (394-402). Ankara: Pegem Akademi Yayıncılık.

Altun, A. (2009). Eğitim Bilim Açısından Seçmeli Medya Okuryazarlı̆̆ı Dersi Programına Eleştirel Bir Yaklaşım. Ahi Evran Üniversitesi Eğitim Fakültesi Dergisi, 10(3), 97-109.

Ananiadou, K. ve Claro, M. (2009). 21st Century Skills And Competences for New Millennium Learners in OECD Countries. OECD Education Working Papers, 4, OECD Publishing.

Arslan, B. ve Dursun, T. (2017). Üniversite Öğrencilerinin Çevreci Reklamlara Yönelik Tutumlarını Etkileyen Demografik Faktörlerin Belirlenmesi: Ampirik Bir Çalışma. Ekonomik ve Sosyal Araştırmalar Dergisi, 13 (1), 161-172.

Arslan, B. ve Candan, B. (2017). İşletme Biliminde Güncel Araştırmalar, Nezihe TÜFEKCİ (Ed.), Bölüm Adı: Sosyal Yenilikçilik ile Teknolojik Yenilikçilik Arasındaki İlişkinin Belirlenmesine Yönelik Ampirik Bir Çalışma, 149-162, Türkiye: SRA Academic Publishing.

Ata, F. ve Baran, B. (2011). Üniversite Öğrencilerinin Bilgi Okuryazarlığı Öz Yeterlik Algılarının Yabancı Dil Düzeyine, Cinsiyete, Bilgisayar Sahipliğine ve İnternet Kullanım Sıklıklarına Göre Incelenmesi. 5th International Computer and Instructional Technologies Symposium, 22-24 September 2011, Firat Üniversitesi, ELAZIĞ.

Ata, F. (2018) Yeni Medyada Gerçeğin Yeni İnşacıları: Okurlar. Erciyes İletişim Dergisi, 5(4), 833-848.

Aydoğan, F. (2009). Eleştirel Perspektiften Yeni Medya. Marmara İletişim Dergisi, 15, 185- 194.

Balcı, A. (2011). Sosyal Bilimlerde Araştırma. Ankara: Pegem Yayıncılık.

Bawden, D. ve Robinson, L. (2009). The Dark Side of İnformation: Overload, Anxiety and Other Paradoxes and Pathologies [Bilginin Karanlık Tarafi: Aşırı Yük, Anksiyete ve Diğer Paradokslar ve Patolojiler]. Journal of Information Science, 35(2), 180-191.

Beşoluk, Ş. ve Önder, İ. (2010). Öğretmen Adaylarının Öğrenme Yaklaşımları, Öğrenme Stilleri ve Eleștirel Düşünme Eğilimlerinin İncelenmesi. İlköğretim Online, 9(2), 679-693.

Binark, M. ve Bek, M. G. (2010). Eleștirel Medya Okuryazarlı̆̆ı. İstanbul: Kalkedon Yayıncllı.

Burnett, C. ve Merchant, G. (2011). Is There A Space For Criticial Literacy İn The Context of Social Media? [Sosyal Medya Bağlamında Eleștirel Okuryazarlık İçin Bir Alan Var Mı? ]. English Teaching: Practice And Critique, 10(1), 41-57.

Considine, D. (2002). Media Literacy Across The Curriculum [Müfredat Boyunca Medya Okuryazarlığ ] ]. Cable In The Classroom: Thinking Critically About Media. 
Cottrell, Stella (2005). Critical Thinking Skills, Developing Effective Analysis and Argument, Basing Stoke: Palgrave Macmillan.

Çepni, O. ve Palaz, T., Ablak, S. (2015). Sosyal Bilgiler Öğretmen Adaylarının Medya ve Televizyon Okuryazarlık Düzeylerinin Çeşitli Değişkenlere Göre İncelenmesi. International Periodical for the Languages, Literature and History of Turkish or Turkic, 10(11), 431-446.

Ciftci, D. ve Evren, F. B. (2018). A New Creative Culture Example: The Case of the 'What will be Happen News Bulletin'in North Cyprus. Online Journal of Communication and Media Technologies, 8(4), 385-398.

Çiftçi, H. (2018). Öğrencilerin Siber Mağduriyet Düzeylerinin Karşılaştırılması. Gümüşhane Üniversitesi Illetişim Fakültesi Elektronik Dergisi, 6(2), 1536-1567.

Çiftçi, H. (2018). Siber Zorbalık Davranışları ve Siber Mağduriyet Düzeylerinin Karşılaştırılması. Anemon Muş Alparslan Üniversitesi Sosyal Bilimler Dergisi, 6(6), 887-897.

Çiftçi, H. (2018). Üniversite Öğrencilerinde Sosyal Medya Bağımlılığı. Manas Journal of Social Studies, 7(4), 417-434.

Çubukçu, A. ve Bayzan, Ş. (2013). Türkiye'de Dijital Vatandaşlık Algısı ve Bu Algıyı İnternetin Bilinçli, Güvenli ve Etkin Kullanımı ile Artırma Yöntemleri. Middle Eastern and African Journal of Educational Research, 5, 148-174.

Dal, S. ve Aktay, S. (2015). İnternet İçin Eleştirel Okuryazarlık Ölçeği Geliştirme Çalışması. Journal of Academic Studies, 17(67),185-199.

De Abreu, B. (2010). Changing Technology: Empowering Students Through Media Literacy Education [Değişen Teknoloji: Medya Okuryazarlı̆̆ı Eğitimi İle Öğrencilerin Güçlendirilmesi ]. New Horizons İn Education, 58(3), 26-33.

Demiralay, R. (2008). Öğretmen Adaylarının Bilgi ve İletişim Teknolojilerini Kullanımları Açısından Bilgi Okuryazarlığı Öz-Yeterlik Algılarının Değerlendirilmesi. Yayımlanmamış Yüksek lisans tezi, Gazi Üniversitesi, Ankara.

Diker, E. ve Taşdelen. B. (2017). Sosyal Medya Olmasaydı Ne Olurdu? Sosyal Medya Bağımlısı Gençlerin Görüşlerine İlişkin Nitel Bir Araştırma. Uluslararası Hakemli Iletişim ve Edebiyat Araştırmaları Dergisi, 17, 189-206.

Dinçer, S. (2017). Ortaokul Öğrencilerinin Bilgisayar Okuryazarlık Düzeylerinin Belirlenmesi ve Ölçme-Değerlendirme Araçlarının Yapısı. İlköğretim Online, 16(3), 1329-1342.

Domine, V. (2011). Building 21st Century Teachers: An İntentional Pedagogy Of Media Literacy Education [21. Yüzyıl Öğretmenleri Oluşturma: Medya Okuryazarlığı Ĕgitiminin Kasıtlı Bir Pedagojisi]. Action İn Teacher Education, 33, 194-205.

Dubey-Jhaveri, A. ve Cheung, C. K. (2016). Media Literacy And Critical Thinking: Perspectives And Pedagogies NJ: Wiley- Blackwell.

Ennis, R. H. (1996). Critical Thinking Dispositions: Their Nature and Assessability [Eleștirel Düşünme Eğilimleri: Doğaları ve Değerlendirilebilirliği ]. Informal Logic, 18 (2), 165-182. 
Erdem, C. (2018). The Relationship Between Media Literacy And Critical Thinking: A Theoretical And Empirical Review. C. Atar (ed.) Cutting Edge Topics And Approaches In Education And Applied Linguistics (62-86). New Castle upon Tyne: Cambridge Scholars Publishing.

Evancho, S. R. (2000). Critical Thinking Skills And Dispositions Of The Under Graduate Baccalaureate Nursing Student, Southern Connecticut State University, Unpublished Master's Thesis, Connecticut.

Facione, Peter A. (1990). The California Critical Thinking Skills Test: College Level,Technical Report 1. Experimental Validation And Content Validity, ERIC Clearinghouse.

Fidan, M. (2013). Sınıf Öğretmeni Adaylarının Medya Okuryazarlık Düzeyleri. Erzincan Üniversitesi Eğitim Fakültesi Dergisi, 15(2), 121-137.

Finegold, D. ve Notabartolo, A. S. (2008). 21st Century Ceompetencies And Their İmpact: An İnterdisciplinary Literature Review. Erişim: 12.10.2018, https://www.hewlett.org/library/21st-century-competencies-impactinterdisciplinary-literature-review/

Fleming, L. (2013). Expanding Learning Opportunities With Transmedia Practices: Inanimate Alice As An Exampler [Transmedia Uygulamaları İle Öğrenme Fırsatları Genişleyen: Bir Örnekleyici Olarak Cansız Alice]. Journal Of Media Literacy Education, 5 (2), 370-377.

Geray, H. (2003). İletişim ve Teknoloji: Uluslararası Birikim Düzeninde Yeni Medya Politikaları. İstanbul: Ütopya Yayınevi.

Gregory, A. E. ve Cahill, M. A. (2009). Constructing Critical Literacy: Self-Reflexive Ways for Curriculumand Pedagogy. Critical Literacy: Theories and Practices, 3(2), 6-16.

Gültekin, N. ve Arslan, B. (2018). İşletme Bilimi Kapsamında Sektörel Araștırmalar İş Dünyasına ve Akademiye Yönelik Değerlendirmeler, Nezihe Tüfekci (Ed.), Şanlıurfa'da Yaşayan Vatandaşların Suriyeli Mültecilere Yönelik Algıları, 259280, Türkiye:.SRA Academic Publishing.

Güngör, N. (2013). İletişim Kuram ve Yaklaşımlar. Ankara: Siyasal Kitabevi.

Güven, İ. (2014). Fen ve Teknoloji Öğretmen Adaylarının Bilgi Okuryazarlığı ve Medya Okuryazarlığı Düzeylerinin İncelenmesi. Turkish Studies, 9(2), 787-800.

Hobbs, R. (2010). Digital And Media Literacy: A Plan Of Action. Washington, DC: The Aspen Institute.

Hoem, J. (2004). Videoblogs as" Collective Documentary". Erişim : 05.10.2018, blogtalk.netpresentBT2Hoem_Jon.pdf

Jolls, T. ve Grande, D. (2005). Project Smartart: A Case Study İn Elementary School Media Literacy And Arts Education. [Proje Smartart: İlkokul Medya Okuryazarlığı ve Sanat Eğitimi Bir Vaka Çalıșması. ]. Arts Education Policy Review, 107(1), 25-31.

Jones-Kavalier, B. R. ve Flannigan, S. L. (2006). Connecting The Digital Dots: Literacy Of The 21st Century [21. Yüzyılın Dijital bağlantı Noktaları: Okuryazarlık]. Educause Querterly, 2, 8-10. 
Kalaycı, Ş, (2006). SPSS Uygulamalı Çok Değişkenli İstatistik Teknikleri. Ankara: Asil Yayın Dağıtım.

Karaman, M. K. (2016). Öğretmen Adaylarının Medya Okuryazarlık Düzeyleri ve Eleştirel Düşünme Eğilimleri Üzerine Bir Araștırma. Gümüşhane İletişim Fakültesi Dergisi, 4(1), 326-350.

Karasu, M. ve Arıkan, D. (2016). Öğretmen Adaylarının Sosyal Medya Kullanım Durumları ve Medya Okuryazarlık Düzeyleri Arasındaki İlişkinin İncelenmesi. Ege Eğitim Dergisi, 17(2), 549-566.

Kellner, D. ve Share, J. (2007). Critical Media Literacy, Democracy And The Reconstruction Of Education. D. Macedo ve S. R. Steinberg (Editörler) Media Literacy: A Reader (3-23). New York: Pater Lang Publishing.

Kellner, D. ve Share, J. (2005). Toward Critical Media Literacy: Coreconcepts, Debates, Organizations, and Policy [Eleștirel Medya Okuryazarlığına Doğru: Coreconcepts, Tartışmalar, Organizasyonlar ve Politika ]. Discourse: Studies in the Cultural Politics of Education, 26 (3), 369-386.

Koltay, T. (2011). The Media And The Literacies: Media Literacy, İnformation Literacy, Digital Literacy [Medya ve Okuryazarlık: Medya Okuryazarlığı, Bilgi Okuryazarlığı, Dijital Okuryazarlık]. Media, Culture and Sociaety, 33(2), 211221.

Korkmaz, Ö. (2009). Eğitim Fakültelerinin Öğrencilerinin Eleştirel Düşünme Eğilim ve Düzeylerine Etkisi. Türk Eğitim Bilimleri Dergisi, 7(4), 879-902.

Korkut, E. ve Akkoyunlu, B. (2008). Yabancı Dil Öğretmen Adaylarının Bilgi ve Bilgisayar Okuryazarlık Öz-Yeterlikleri. Hacettepe Üniversitesi Ĕ̆itim Fakültesi Dergisi, 34, 178-188.

León, Y. Z. (2016). Media Literacy To Promote Critical Thinking in The EFL Classroom. Unpublished Master's Thesis,Universidad Distrital Francisco José De Caldas, Colombia.

Masterman, L. (2005). Teaching The Media. Taylor And Francis E-Library.

McLaughlin, M. ve DeVoogd, G. L. (2004). Critical Literacy as Comprehension: Expanding ReaderResponse. Journal of Adolescent \& Adult Literacy, 48, 52-62.

Mkandawire, M. T. ve Walubita, G. (2015). Feedback Study On Developing Critical Literacy Among Malawian and Zambian Undergraduate University Students Using a Freirean Praxis [Freirean Praxis Kullanarak Malavi ve Zambiya Lisans Üniversite Öğrencileri Arasında Eleştirel Okuryazarlık Geliştirme Konusunda Geribildirim Çalışması ]. Journal of Education And Training Studies, 3(2), 150158.

Mohammadyari, S., and Singh, H. (2015). Understanding The Effect Of E-Learning on İndividual Performance: The Role Of Digital Literacy [E-öğrenmenin Bireysel Performans Üzerindeki Etkisini Anlamak: Dijital Okuryazarlığın Rolü]. Computers and Education, 82, 11-25.

Moore, K. D. (2001). Classroom Teaching Skills. Boston: Mcgraw-Hill. Ofcom Media Literacy Bulletin. Erişim Tarihi: 14. 10.2018, www.ofcom.org.ukadvicemedia_ literacymedlitpubbulletinsissue7.pdf 
Mutlu, E. (2004). İletişim Sözlüğü. Ankara: Bilim ve Sanat.

Özbay, M. ve Özdemir, O. (2014). Türkçe Öğretim Programı İçin Bir Öneri: Dijital Okuryazarlığa Yönelik Amaç ve Kazanımlar. Okuma Yazma Eğitimi Araştırmalarl, 2 (2), 31-40.

Paul, Richard W. (1991). "Staff Development for Critical Thinking: Lesson Plan Remodelling as The Strategy", A.L. Costa(Edit.), Developing Minds Revised Education, Virginia: ASCD.

Pérez Tornero, J. M. and Varis, T. (2010). Media Literacy and New Humanism. Moscow: UNESCO, Institute For Information Technologies in Education.

Piji Küçük, D. ve Uzun, Y. B. (2013). Müzik Öğretmeni Adaylarının Eleștirel Düşünme Eğilimleri. Ahi Evran Üniversitesi Kırşehir Eğitim Fakültesi Dergisi, 14(1), 327345.

Potter, W. J. (2010). The State Of Media Literacy [Medya Okuryazarlığı Durumu ]. Journal of Broadcasting and Electronic Media, 54(4), 675-696.

Potter, W. James (2004). Theory of Media Literacy: A Cognitive Approach. Washington: SAGE.

Prior, D. D., Mazanov, J., Meacheam, D., Heaslip, G., and Hanson, J. (2016). Attitude, Digital Literacy and Self Efficacy: Flow-On Effects for Online Learning Behavior. [Tutum, Dijital Okuryazarlık ve Öz Etkinlik: Online Öğrenme Davranışı İçin Akış Etkileri]. The Internet and Higher Education, 29, 91-97.

Radovanović, D., Hogan, B., and Lalić, D. (2015). Overcoming Digital Divides İn Higher Education: Digital Literacy Beyond Facebook [Yüksek Öğretimde Dijital Okuryazarlığın Üstesinden Gelmek: Facebook'un Ötesinde Dijital Okuryazarlık ]. New Media and Society, 17(10), 1733-1749

Redmond, T. (2016). Learning to Teach the Media: Pre-Service Teachers Articulate The Value of Media Literacy. M. Yıldız Ve J. Keengwe (Editörler), Handbook of Research on Media Literacy in The Digital Age (31-52). Hershey, PA: IGI Global.

Salpeter, J. (2008). 21st Century Skills: Will Our Students Be Prepared? Tech and Learning.

Sarsar, F. ve Engin, G. (2015). Sınıf Öğretmeni Adaylarının Medya Okuryazarlık Düzeylerinin İncelenmesi. Ege Eğitim Dergisi, 16(1), 165-176.

Schwarz, G. (2001). The Role of Media Literacy in Teacher Education. [Öğretmen Eğitiminde Medya Okuryazarlığının Rolü]. Teacher Education Quarterly, 28(2), 111-119.

Scull, T. M. ve Kupersmidt, J. B. (2012). An Evaluation of a Media Literacy Program Training Workshop for Late Elementary School Teachers. [Geç İlkokul Öğretmenleri İçin Bir Medya Okuryazarlığı Programı Eğitim Çalıştayı Değerlendirilmesi ]. J Media Lit Educ, 2(3), 199-208.

Sevim, F. (2013). Medya Okuryazarlığı, Toplumsal Cinsiyet ve Kadının Medyada Temsili. Yayımlanmamış Yüksek Lisans Tezi, İstanbul Ticaret Üniversitesi, İstanbul.

Silverblatt, A., Smith, A., Miller, D., Smith, J. ve Brown, N. (2014). Media Literacy: Keys to Interpreting Media Messages. Santa Barbara: Praeger. 
Som, S. ve Kurt, A. A. (2012). Bilgisayar ve Öğretim Teknolojileri Eğitimi Bölümü Öğrencilerinin Medya Okuryazarlık Düzeyleri. Anadolu Journal Of Educational Sciences International, 2(1),104-119.

Sönmez, E. E. ve Gül, H. Ü. (2014). Dijital Okuryazarlık ve Okul Yöneticileri. 19. Türkiye'de İnternet Konferansl. Erişim: 05.10. 2018, http://inet-tr.org.tr/ inetconf19/ozet/69.html

Steinbrink, J. E. ve Cook, J. W. (2003). Media Literacy Skills and The War on Terrorism. [Medya Okuryazarlığı Becerileri ve Terörizm Savaşı]. The Clearing House, 76(6), 284-288.

Şen, Ü. (2009). Türkçe Öğretmeni Adaylarının Eleştirel Düşünme Tutumlarının Çeşitli Değisşkenler Açısından Değerlendirilmesi. Journal of World Of Turks, 1(2), 69-89.

Thoman, E. ve Jolls, T. (2008). 21. Yüzyıl Okuryazarlığı. (Cevat Elma ve Alper Kesten, Çev.), Ankara: Ekinoks Yayınları.

Trilling, B. ve Fadel, C. (2009). 21st Century Skills: Learning For Life In Our Times. San Fransisco: Jossey-Bass.

Tüzel, S.ve Tok, M. (2013). Öğretmen Adaylarının Dijital Yazma Deneyimlerinin İncelenmesi. Tarih Okulu Dergisi (TOD), 6(15), 577-596.

Uslu, S., Yazıcı, K. ve Çetin, M. (2016). Sosyal Bilgiler Öğretmen Adaylarının Medya Okuryazarlık Düzeyleri. Adıyaman Üniversitesi Sosyal Bilimler Enstitüsü Dergisi, 8(23), 756-778.

Ulaş, S. (2018). Lüks: Dünü ve Bugünü. Sosyal, Beşeri ve İdari Bilimler Alanında Akademik Çalışmalar. Gece Kitaplığı. Cilt 2, 55: 855-868.

Wagner, T. (2008). The Global Achievement Gap: Why Even Our Best Schools Don't Teach the New Survival Skills Our Children Need - And What We Can Do About It. New York: Basic Books.

Yllmaz, E. ve Aladağ, S. (2015). Sınıf Öğretmeni Adaylarının Gazete ve Dergi Takip Etme Alışkanlıkları İle Medya Okuryazarlık Düzeyleri Arasındaki İlişki. Ușak Üniversitesi Sosyal Bilimler Dergisi, 8(4), 1-15. 